\title{
Younger Wine Tourists: A study of generational differences in the cellar door experience. ${ }^{1}$
}

\author{
Dr. Joanna Fountain, Environment, Society \& Design Division, Lincoln University, New Zealand ${ }^{2}$; \\ Dr. Steve Charters, School of Marketing, Tourism and Leisure, Edith Cowan University, Western \\ Australia.
}

\section{INTRODUCTION AND CONTEXT}

The importance for wineries of visitation to cellar doors is recognised by both the tourism and wine industries (O'Neill and Charters, 2000). The quality of cellar door service plays a central role in the tourist's experience of a winery and in the emotional attachments a tourist develops for a brand, and by implication, the future purchase intentions of that tourist (Charters and O'Neill, 2001; Dodd and Bigotte, 1997; Nixon, 1999;). Understanding cellar door expectations and experiences from the point of view of the wine tourist is essential to allow wineries to establish this loyalty (O'Neill and Charter, 2000). This chapter reports on research which examined the perceptions and experience of visitors to winery cellar doors in one wine region of Western Australia. It particularly focused on the perspective of younger wine tourists, who for current purposes are defined as those that are members of the Generation $\mathrm{X}$ and Generation $\mathrm{Y}$ cohorts, and sought to compare their experience and expectations of winery cellar doors with those of older wine tourists.

\section{LITERATURE REVIEW}

A number of articles have appeared over the past decade exploring the issue of visitors' satisfaction with the service quality experienced at the cellar door (Ali-Knight and Charters, 2001; Morris and King, 1997). To date, however, very little research has explored the significance of age or generational differences of the wine tourist as a factor in the service quality experienced at the winery cellar door (exceptions include Mitchell, 2002; Treloar, 2002). While Mitchell's (2002) study found no significant generational differences in satisfaction with the winery experience,

\footnotetext{
${ }^{1}$ The authors would like to thank The Vines resort, in the Swan Valley, for their invaluable hospitality in carrying out this research, and Freya Powell for her assistance in preparing the study.

${ }^{2}$ Corresponding Author - fountaij@lincoln.ac.nz. Research completed while a staff member of Edith Cowan University
} 
glimpses of age-related factors affecting cellar door experiences have at times emerged from other more general investigations of the characteristics and experiences of wine tourists. Dodd and Bigotte (1997) found evidence that older people were generally less critical of their winery experience than younger visitors, and that younger wine tourists rated service quality as a more important factor in determining their satisfaction with the winery visit than their older counterparts. What has not been investigated, however, is whether the lower satisfaction of younger wine tourists was due to differing priorities at the cellar door, or to differential experiences of service quality at the winery. This is particularly significant given the aging Baby Boom generation and the growing disposable income of their offspring. In this context, there is a need to foster an interest in wine amongst Generation $\mathrm{X}$ and Generation $\mathrm{Y}$ in order to ensure the long-term survival of the wine industry (Beverland, 2001; Bruwer, 2002; Howard and Stonier, 2001; Mitchell, 2002; Treloar, 2002).

There is much disagreement about the start and end dates of Generation X, although the definition used in this context - that is, people born in the period 1964 and 1979 - is an accepted definition (King, 2001). Generation Y are defined as those born since 1979, meaning that at the time of this research (2004), the cohort of Generation $X$ were aged between 25 and 40, while those in Generation $\mathrm{Y}$ were 24 and below. In this paper, these two age group are referred to as 'younger wine tourists', and their experiences are compared with the 'older wine tourists, who were aged between 44 and 65 (Baby Boomer and Mature generation).

It is recognised that the characteristics of Generation $\mathrm{X}$ are quite difficult to pin down (Beverland, 2001) however some attempts have been made to identify their key characteristics. Firstly, they are generally viewed as a generation marked by an independent spirit (King, 2001; Martin and Tulgan, 2001). They are a sceptical and non-committal generation, meaning that establishing brand loyalty is difficult (King, 2001). One defining factor of Generation $\mathrm{X}$ is their demand for recognition of their individual needs as consumers (Beverland, 2001). For this reason, experiencing the personalised service of a winery cellar door is a significant factor in the wine purchasing process, as is the recommendations of family and friends (Howard and Stonier, 2001). There is evidence also that Generation X wine tourists will be more likely to develop a relationship with, and brand loyalty to, a winery with well-trained and knowledgeable staff (Treloar, 2002). While Generation X are yet to register as significant consumers of wine, there is evidence that this cohort is beginning to recognise the appeal of the wine tourism experience and participate in wine tourism activities, 
particularly wine events and festivals, in greater numbers (Houghton, 2001; Mitchell, 2002; Nixon, 1999)

Generation Y, also referred to as the Echo-Boomers or Millennium Generation, currently irregular wine drinkers, as according to one report 'when young adults begin drinking, wine doesn't factor into the equation at all' (cited in Scalera, 2002, p.2). This group's early experience of alcohol begins with experimenting with alcoholic beverages in pubs, clubs and bars where the pressure to try wine is far less than it is to consume beer and spirits (Scalera, 2002). Generation Y are a confident cohort - comfortable with evolving technologies, self-reliant, ambitious, tolerant of others and eager for a challenge (Hofman, 1999; King, 2001; Martin and Tulgan, 2001). This openness to change may provide an important opportunity to wine marketers and cellar door operators, if they are able to identify products and experiences which appeal to these young adults.

\section{RESEARCH METHOD}

Quantitative studies exploring perceptions of cellar door service have been carried out in other regions using exit questionnaires (Charters and O'Neill, 2000; O'Neill and Charters, 2000), but in this instance it was felt a qualitative approach could yield a different perspective and shed new light on the cellar door experience. To this end, the researchers chose to make use of participant observers, fulfilling roles close to that of 'mystery shoppers', who would experience service at the cellar door and then report on it via a brief questionnaire, followed by a focus group discussion.

Mystery shopping is a form of covert participant observation in which researchers take on the role of customers or potential customers in order to 'monitor the processes and procedures used in the delivery of a service' (Wilson, 1998, p.148). The potential of observational methods for investigating service provision is increasingly acknowledged (Grove and Fisk, 1992; Wilson, 1998), and mystery shopping has been used extensively in the services industry to investigate service quality. However, it has rarely been used in academic research on tourism to date (see Hudson et al., 2001).

The research was conducted at cellar doors in the Swan Valley region of Western Australia. The Swan Valley is a small wine producing region about forty minutes drive to the east of Perth. It has a long history of wine production, but is a hot region, and in recent years its importance to Western Australian wine production has been eclipsed by Margaret River. Nevertheless, its proximity to 
Perth makes it a popular destination for day tourists, and a number of organised visits to the region are offered by tourism operators.

To investigate cellar door service in the Swan Valley, twenty-four mystery shoppers were sent out in four groups. Each group consisted of three generationally-defined pairs (one pair each of older wine tourists, Generation X and Generation Y). Variables other than age that might influence the experiences of the participants (such as gender, travel party size and race) were controlled for as much as possible in the mystery shopping exercise. The groups visited two wineries each; four wineries were visited in all. Consequently there were a total of eight visits, with each winery being visited by twelve mystery shoppers (two groups of six). The mystery shoppers were given a general perspective on the study, but were not advised that age-related issues were important. They were advised to treat their visit as a normal, pleasurable exercise. On leaving the cellar door each mystery shopper completed a short questionnaire about their visit.

While the mystery shopping exercise is useful for exploring the provision of service at the cellar door, this research set out to investigate the whole process of cellar door service, including both the service received by the mystery shoppers and their expectations of the cellar door experience. In order to explore the demand side of the service equation, the mystery shoppers were debriefed in a focus group setting. These focus groups discussed the cellar door experience in more detail, particularly the relationship between the expectations and experiences of the participants.

\section{FINDINGS}

\section{Differences in expectations}

There appeared to be some variation in the expectation that each generational group had of the cellar door experience. Critically, the younger wine tourists (Generation X and Y) appeared to place more emphasis on enjoying the entire experience, rather than explicitly focusing on the wine. Typifying this viewpoint, one Generation $\mathrm{Y}$ respondent wrote on his questionnaire that '[w]hen wine tasting with friends having a good time ... is more important than tasting the wine'. During focus group discussions, this informant stated that while he didn't like the wines at one winery, 'I liked the atmosphere' and would be keen to return to the winery with friends because it was not too 'posh' or intimidating. This perspective was mirrored on a number of occasions by the Generation $\mathrm{Y}$ and Generation $\mathrm{X}$ informants. 
There was evidence also that the younger informants expected to interact with the staff at the cellar door more than their older counterparts. For these visitors it was important that the process involved a personalised service - perhaps even a relationship - rather than merely exchanging information or goods. This compared with the comments of the older visitors, who appeared to concentrate much more closely on their response to the wine tasted. A good example of this distinction focused on attitudes to personal space within the environment of the cellar door. One older visitor commented:

Once they had given you the wine to taste they would actually stand back and allow you [to try it] .... I liked that attitude of standing back, and allowing us to actually speak to each other, and also just taste the wine (female, Baby Boomer).

This view was echoed explicitly by other older informants at different encounters. Yet a Generation $\mathrm{X}$ informant wrote of the same cellar door that she felt that the staff 'stood back and were not keen to serve', and another, Generation Y, informant, commented disapprovingly that the staff stood a long way away from them.

The focus of younger visitors on the service experience, rather than the wine tasted, also appeared to produce varying expectations of the organisation of the encounter. Older visitors apparently preferred a more structured, 'systematic' approach to the tasting process. One Mature participant expressed satisfaction that the staff member serving her followed a set approach 'rigorously'. This expectation contrasted with the preference of younger visitors who searched for a more flexible, rather than structured, experience. Younger wine visitors seemed to place a lot of emphasis on being asked their needs in the service experience, and having those needs met. This seemed especially true of the Generation $\mathrm{X}$ group. For example, a Generation X informant enjoyed his winery visit, but felt more interest could have been shown in his needs, commenting ' $I$ just feel that ... would be part of the service .... [They should] try and find what the customer ... would like. And then you could ... direct them towards something'. Such comments were non-existent from the older visitors, but frequent amongst younger wine tourists, with a Generation $\mathrm{X}$ female expressing a similar opinion about service at a different winery:

It was very professional, but I really didn't find that the chap had a lot of interest in what my needs were, what wines I like tasting, what my experience was of the previous wines I'd liked. [There was] no recommendation about anything else. 


\section{Differences in treatment}

One general point is worth recording about the informants' experience at the cellar door, which is that the older visitors generally were far more satisfied with the experience than the younger informants. Only in one out of the eight visits did a single older visitor appear dissatified with the experience. The younger generational groups were less sanguine. It seems possible that, in fact, the Generation $\mathrm{X}$ informants were marginally less satisfied with the experience than those from Generation Y.

In three out of the eight cellar door encounters there was some suggestion that cellar door staff were inclined to treat younger visitors less positively than older ones; in two cases, the pairs from Generation $\mathrm{X}$ and $\mathrm{Y}$ were treated similarly, while in the other case it was the Generation Y mystery shoppers that were alone in being less-well treated. In this latter example, all three pairs felt generally welcomed at the winery in question. However, the cellar door staff appeared to discriminate against the Generation $\mathrm{Y}$ visitors in terms of the wines they were offered to taste. The winery has a flagship red wine (referred to here as 'the Icon'), which retails at around $\$ 30$, and is not generally available for tasting at the cellar door. However, on the afternoon of this visit the wine could be tasted, and was offered both to the older couple and Generation $\mathrm{X}$ pair, who commented approvingly on it. One of the Generation Y pair, who had explicitly expressed a preference for red wine, was interested in the Icon, and noted the positive response of a Generation $\mathrm{X}$ female, so asked about the wine. The staff member, who had served the wine to the other two pairs, casually said 'oh, that's the Icon', but did not offer a sample to the Generation Y pair, who left without trying it.

It is worth noting that any instances of preferential treatment only seemed to occur when the cellar door was not busy. It is possible that preferential treatment to older visitors, where it exists, can only be the product of a cellar door with the luxury of time to make choices about how its visitors are handled.

\section{IMPLICATIONS}

It has previously been suggested that wine tourists are not a culturally homogeneous body (Charters and Ali-Knight, 2002; Mitchell et al., 2000). This exploratory research implies that they are not generationally homogeneous either, having varying expectations of the cellar door encounter. The 
findings suggest that the older visitors place a greater emphasis on the product (shown also in their preference for 'space' in which to taste) while younger visitors (Generation $\mathrm{X}$ and $\mathrm{Y}$ ) give more importance to the overall experience and the service they receive, and can be explicit that the quality of the wine is secondary to them.

This suggests that Generations $\mathrm{X}$ and $\mathrm{Y}$ visitors require a different focus from those who staff the cellar door. They seem to say 'I want them to be interested in me' - seeking a flexible, empathetic service, rather than a transactional, structured one. Such an approach reflects the suggestion that Generation $\mathrm{X}$ require recognition of their individual needs as consumers, combined with a preference for the relaxed and the informal (Beverland, 2001). The more 'refined' cellar door may actually be off-putting to them, even if it is preferred by the older visitors. It is worth noting in this instance that Generation Y visitors seem especially ill at ease in the cellar door environment, perhaps belying the suggestion that they are a 'confident' and 'self-reliant' group (Martin and Tulgan, 2001).

Younger visitors seem generally a bit more critical of cellar door service than older visitors, which may be especially true of the Generation X group, perhaps confirming their alleged 'scepticism' (King, 2001). However, it is worth asking if older wine tourists are happier with the experience because they are better treated, or because they come with different expectations of the encounter which are more easily fulfilled. It is natural to expect a winery to focus on the quality of the wine, rather than the quality of the experience, and in doing so they may be overlooking the demands of younger wine tourists.

Nevertheless, it also seems that there may be instances when cellar door staff give preferential treatment to older visitors, a fact which may be noted by members of Generations $\mathrm{X}$ and $\mathrm{Y}$. This occurred at three different wineries, but was not replicated in the second visit to any of those wineries. If this is correct, then two conclusions may be drawn from this. One is that there may be a culture of bias in some wineries, which is less apparent when the winery is busy. The other interpretation is that such preferential treatment is not built into the winery's culture, but is practised by individual members, or teams, of cellar door staff. In either case, however, it is the winery which has overall responsibility for such behaviour.

These issues are crucial for wineries providing a cellar door service. The future importance of Generation $\mathrm{X}$ as a customer base has been noted (Beverland, 2001; Bruwer, 2002; Howard and 
Stonier, 2001). Nevertheless, there appears to be some evidence that cellar door managers' 'ideal' customer is an older, professional male (Charters and O'Neill, 2000), a notion that only supports short or mid-term brand development. An environment in which younger visitors feel at ease, and which they leave satisfied, is crucial to developing long-term brand loyalty for the business. Just as important to brand loyalty is ensuring that they give no appearance of preference for one group of customers over another.

It is necessary to observe that this research has clear limitations. It took place only in one, small, Australian wine region. It was exploratory in nature. Crucially the gender balance of the Generation $\mathrm{X}$ and $\mathrm{Y}$ mystery shoppers was uneven. The study was too small-scale to allow an analysis of gender differences or other differentiating characteristics in varying generational responses to the cellar door experience, an issue which needs to be addressed in further research.

\section{REFERENCES}

Ali-Knight, J. and Charters, S. (2001) The winery as educator: Do wineries provide what the wine tourist needs? Australian and New Zealand Wine Industry Journal 16, 79-86.

Beverland, M. (2001) Generation X and wine consumption. Wine Industry Journal 16, 91-96.

Bruwer, J. (2002) Marketing wine to Generation X consumers through the cellar door. The Australian \& New Zealand Grapegrower \& Winemaker December [online edition]. Available: http://www.grapeandwine.com.au/dec02/07.htm [accessed 28 Nov. 2003].

Charters, S. and Ali-Knight, J. (2002) Who is the wine tourist? Tourism Management 23, 311-319.

Charters, S. and O'Neill, M. (2000) Delighting the customer - how good is the cellar door experience? International Wine Marketing Supplement 1, 11-16.

Charters, S. and O'Neill, M. (2001) Service quality at the cellar door: A comparison between regions. International Journal of Wine Marketing 13, 7-17.

Dodd, T. and Bigotte, V. (1997) Perceptual differences among visitor groups to wineries. Journal of Travel Research 35, 46-51. 
Grove, S.J. and Fisk, R. (1992) Observational data collection methods for services marketing: An overview. Journal of the Academy of Marketing Services 20, 217-24.

Hofman, M. (1999) Upstarts: Tapping Generation Y. Inc. Magazine (Dec.) [online edition] http://www.inc.com/magazine/19991201/15689.html [accessed 18 Jan. 2004].

Houghton, M. (2001) The propensity of wine festivals to encourage subsequent winery visitation. International Journal of Wine Marketing 13, 32-52.

Howard, R. and Stonier, J. (2001) Marketing wine to Generation X: the way ahead. The Australian Grapegrower \& Winemaker (Dec.), 69-71.

Hudson. S., Snaith, T., Miller, G.A. and Hudson, P. (2001) Distribution channels in the travel industry: Using mystery shoppers to understand the influence of travel agency recommendations. Journal of Travel Research 40, 148-154.

King, D. (2001) Defining a generation: Tips for uniting our multi-generational workforce. Available: http://www.careerfirm.com/index.html [accessed 12 Jan. 2004].

Martin, C.A. and Tulgan, B. (2001) Managing Generation Y: Global citizens born in the late seventies and early eighties. HRD Press, Amherst Massachusetts.

Mitchell, R. (2002) The generation game: Generation X and baby boomer wine tourism. In Proceedings of the New Zealand Tourism and Hospitality Research Conference, 3-5 December, Waiariki Institute of Technology, Rotorua.

Mitchell, R., Hall, M. and McIntosh, A. (2000) Wine tourism and consumer behaviour. In: Hall, M., Sharples, L., Cambourne, B., Macionis, N., Mitchell, R. and Johnson, G. (eds.) Wine tourism around the world: Development, management and markets. Elsevier Science, Oxford, pp. 115-135.

Morris, R. and King, C. (1997) Cooperative marketing for small business growth and regional economic development: A Case study in wine tourism. Proceedings of the USABE Annual National Conference - Entrepreneurship: The Engine of Global Economic Development, San Francisco. Available: http://www.usasbe.org/knowledge/proceedings/1997/index.asp [accessed 4 Dec. 2003]. 
Nixon, B. (1999) The changing face of the winery tourist. Proceedings of Wine Tourism: Perfect Partners - Australian Wine Tourism Conference, Margaret River, Western Australia, pp. 209-217.

O'Neill, M. and Charters, S. (2000) Service quality at the cellar door: implications for Western Australia's developing wine tourism industry. Managing Service Quality 10, 112-123.

Scalera, B. (2002) New ideas for a new generation. Harpers (July) [online edition]. Available: http://www.winexwired.com/archives/harpers2.htm [accessed 6 Jan. 2004].

Treloar, P. (2002) An investigation into the significance of relationship marketing on the young winery tourist. Proceedings of the New Zealand Tourism and Hospitality Research Conference, 3-5 December, Waiariki Institute of Technology, Rotorua.

Wilson, A.M. (1998) The use of mystery shopping in the measurement of service delivery. The Service Industries Journal 18, 148-163. 